\title{
ВІРТУАЛЬНА РЕАЛЬНІСТЬ У СИСТЕМІ НОВИХ МЕДІА
}

\author{
Юліана Лавриш \\ Львівський національний університет імені Івана Франка, \\ вул. Генерала Чупринки, 49, 79044, Львів, Україна \\ e-mail: newmedialnu085@gmail.com \\ https://orcid.org/0000-0002-5205-9309
}

У публікації представлено простір віртуальної реальності, їі специфіку та важливість саме для формування та розвитку нових медіа. Віртуальна реальність не є ілюзією, а паралельно витвореною реальністю за допомогою цифрових технологій. Віртуальна реальність та реальна дійсність - два виміри, що співіснують у технологічному суспільстві. Саме простір віртуальної реальності відкриває нові можливості для нових медіа та нових нових медіа, а це дозволяє виходити не лише на інший інформаційний рівень, а й розширити горизонти медійного ринку.

Ключові слова: віртуальна реальність, нові медіа, нові нові медіа, Web 2.0.

Виклики цифрової епохи, формату Web 2.0, дають нам підстави дедалі більше поринати у простір Мережі, шукаючи відповіді на ті чи інші питання. Зрештою, ті поняття, які ми досліджували і використовували раніше, дають підстави думати над новими викликами. Наприклад, започаткований у 1954 році термін «соціальна мережа» (Джеймс Барнс), означав зовсім інше, ніж тепер. Тоді Барнс мав на увазі певну групу людей, залучену до свого експерименту, що становили прихожани однієї із парафій у Норвегії, які поза церквою не вели активного спілкування. Дослідник намагався зрозуміти, як функціонує ця соціальна група через зустрічі у храмі, її комунікаційні можливості [5; 109].

Сьогодні «соціальна мережа» - це багатоформатний феномен, зважаючи на вимip Web 2.0. Це не лише задоволення комунікаційних потреб, але й використання всіх основних характеристик мережевого простору: мультимедійність, інтерактивність, створення віртуальної особистості, можливість зворотного зв'язку, творення іміджу. Саме тому актуальність нашого дослідження - у представленні феномену формату Web 2.0, зокрема віртуальної реальності для функціонування і розвитку нових медіа.

Зазначена актуальність визначає мету - осмислити і проаналізувати, наскільки явище віртуальної реальності є підставою для творення нових і нових нових медіа. Вказана мета передбачає виконання таких завдань:

- проаналізувати феномен віртуальної реальності у форматі Web 2.0;

(С Лавриш Ю., 2019 
- визначити, як віртуальна реальність впливає на зміну формату комунікації та медійний простір загалом;

- осмислити, чи перетинає віртуальна реальність матеріальну реальність, чи створює на своєму перетині платформу для розвитку нових медіа;

- визначити, як змінюватимуться нові нові медіа у порівнянні з новими медіа.

Дослідження проведено на основі фондів бібліотеки Зальцбурзького університету (Австрія) у межах тритижневого стажування Австрійського бюро кооперації освіти та досліджень (OeAD) для молодих науковців у листопаді 2018 року. До нашого дослідження ввійшли покликання на праці: Пола Левінсона, Сари Кеслер, Маршала Маклюена, Алана Абрама, Патріс Флітчі.

Отож середовище Інтернету дає підстави окреслювати нам простір нового середовища віртуальної реальності, яка має на меті відображувати наш дійсний, реальний світ, проте у дещо іншому фокусі. На думку групи американських вчених-медіадослідників формат віртуальної реальності прямо пропорційний до нашої візуальної культури. «Коли ми міркуємо про відеоігри, що мають мобільні аналоги для перегляду чи використовуються як аватари, маємо розуміти, що перебуваємо у стані всесвітньої гри, такого собі IMAX-кінотеатру, який містить у собі відчуття місця бачення, так само, як онлайн-банкінг чи онлайн-галереї [5; 125].

3 погляду користувача Мережі, віртуальна реальність є своєрідним вигаданим простором із, звичайно, ерзацом дійсності. Проте все ж це не ілюзія. На думку Мартіна Лістера, тут можна навести приклад із богослов’я. Наприклад, щодо Таїнства Євхаристії. Безумовно, коли ми споживаємо Святе Причастя, ми не буквально вживаємо тіло Христа і п’ємо кров. Через віру віртуально і символічно робимо цю дію, і вона реальна у певному сенсі [5;125]. Отож віртуальність не може бути ілюзією, вона радше є антонімом до «актуальності», хоча і віртуальність, і актуальність $\epsilon$ реальними, проте у різний спосіб. Знову-таки, віртуальна реальність і реальна дійсність, безумовно, різні поняття, хоча вони і співіснують у технологічних суспільствах.

Коли розглядаємо віртуальну реальність, то дедалі більше корелюємо це поняття із симуляцією та симулякром, про що зазначав Жан Бодріяр у своїй однойменній праці [5;126]. Симуляція апелює до симулякра, наче поняття ілюзії до неправдивих образів. Варто зазначити, що віртуальна реальність формує певну панораму образів і сенсів, вона може потрапити у реальний світ, якщо ми матеріально переносимо цю систему образів через копії, носії інформації, гаджети.

На думку групи американських дослідників віртуальної реальності, віртуальність близька до симуляції через:

- комп'ютерний дизайн, графіку, а отже симуляцію образів і подій, які ніколи не відбудуться;

- програмне забезпечення, яке як «текстова мапа» цифрово генерує візуальні форми та об'єкти;

- анімація;

- робот-машини;

- технології, які переміщують особистість у просторі і часі у віртуальні локації, через дотик, запах;

- синоптичні карти Землі та космосу [5; 126].

Зважаючи на технологічні можливості, віртуальна реальність дозволяє створити також майданчик для спілкування. Тут важливо говорити у цьому контексті 
про міжперсональну комунікацію. «Важливість Інтернету та вебу не $є$ альтернативою друку. Більше Мережа нагадує комунікаційний і дискусійний майданчик, коли здійснюється модерація через персональні зв’язки» [c.83]. Варто зазначити, що перш за все простір віртуальної реальності творить своєрідний зразок реального соціуму. Стівен Дж. Джонс називає цей процес «метафорою громади» [8; 105].

Середовища у Мережі творять свій особливий простір, намагаючись відображувати реальну дійсність. Проте віртуальна реальність для творення віртуальної громади все ж вимагає окремі меседжі, можливості, знову-таки медіа і жанри, що дозволяють спілкуватися у веб-просторі. Варто зазначити, що такі віртуальні громади $є$ дієвими або ж ні. Якщо йдеться про недієві громади, то дослідники нових медій також чимало пишуть про «віртуальні кладовища» - це акаунти у соціальних мережах тих користувачів, які реально померли, але віртуально живуть і надалі. На пам'ять про померлих близьких родичі цих користувачів не знищують сторінки, а, навпаки, вітають їх з Днем народження, святами чи щось публікують. Отож у такому аспекті віртуальна реальність є своєрідним ментальним продовженням дійсності.

У віртуальних середовищах відбувається також генерація ідей та принципів. Якщо у традиційних медіа $\epsilon$ класичний поділ на авторів контенту та реципієнтів, то у нових медіа генерація ідей відбувається колоподібно: кожен автор може стати користувачем і навпаки [8;130]. Пол Левінсон у своїй праці «Soft Edge» наводить приклад користувача із Клівленда (США), який пише пост про улюбленого письменника, після чого його пост коментують користувачі з Лондона, Сан-Франциско i, врешті-решт, коментарі та власний текст автора творять нову композицію з нових ідей [8;131]. Гадаємо, що це ще один феномен онлайн-спільноти - бути абсолютно глобальними у просторі і часі без локальної сегментації.

Тому простір віртуальної реальності, на відміну від дійсності, не обмежений територіальними, національними, мовними межами. Члени цієї онлайн-громади жителі світу. А це, у свою чергу, дозволяє віртуальній реальності творити глобальний ринок ідей та нових концептів. Про це зазначає також і американська дослідниця Сара Кейслер: «Онлайн-спільноти існують в асинхронічному часі і без позначеної локації. У результаті вони покладаються, більш, ніж звичайно на традицію комунікаційної практики. Це означає трансформацію індивідуальних користувачів від суміші голосів до конкретної групи» [1;119]. Звичайно, що у цьому контексті відбувається перегук із працею Маршала Маклюена «The Medium is a Massage», в якій автор наводить відому журналістикознавчому товариству концепцію «глобального села», яке твориться на основі використання нових технологій та можливостей комунікації $[10 ; 235]$.

У своїй праці «Understanding the Web» Алан Б. Албарран та Девід Г. Гофф наводять у порівняння не лише концепт МакКлюена, але набагато раніше висловлений у праці «Future Shock» Елвіна Тоффлера концепт «каїрського базару», на якому різні культурні напрями переплітаються та співіснують заради людського життя [10; 212]. «Веб презентує новий стиль у медіа, який трансформується через підтримку культури; як результат - ці хаотичні середовища об'єднуються у індустріальні глобальні села, що є посеред виникнення постіндустріального «світового базару» [10; 236]. Отож концепти обох вчених, зважаючи на прогресивний розвиток віртуальної реальності, взаємодоповнюють один одного, оскільки містять у собі нові виклики та можливості. 
Лавриш Ю

Варто зазначити, що окрім глобалізаційного принципу творення спільноти, у Мережі існує певний поділ на бідних та багатих користувачів, хоча у демократичному сенсі у вебі наявні демократичні процеси, здатні поділити аудиторію на тих, хто є активним і пасивним [7; 4]. Окрім того, що контент Мережі є здебільшого безкоштовним, все ж чимало сервісів знову-таки просять оплату за власні послуги. «Онлайн-суспільство твориться на основі паралельних комунікаційних систем: одне - на прибутку: освітніх зв’язках, даючи чимало нової інформації дешево і з високою швидкістю; інше - на тих, хто без зв'язків, заблокованих часовими бар'єрами, оплатою і неможливістю отримати інформацію» [7; 6].

Виявляється, що глобальне охоплення віртуальної реальності і творення велетенської світової громади ще не означає, що вхід для всіх учасників не є цілком відкритим і доступним. Технології вебу, зважаючи на внутрішню монетизацію ресурсів, прагненню заробляти кошти, творять ринок, дещо схожий на принципи традиційних медій - ти платиш за кожну окрему газету, так само, як і за прочитання публікації чи блогу у популярному веб-ресурсі.

Саме тому, зважаючи на можливості витримки демократизації процесів, без поділу на бідних і багатих, виникають нові нові медіа, про які говоритимемо дещо нижче. Знову-таки, звертаючись до концепту МакЛюена, Пол Левінсон у своїй праці «Digital McLuhan» зазначив, що онлайн-бізнес користується моделлю «глобального села» задля залучення свого потенційного покупця: «Найбільш радикальний онлайн-бізнес повністю наслідує ідеал віртуальної онлайн-спільноти, у якій продукти так само, як і оплата, виключно проводитимуться онлайн - через сервіси та кошти, які повністю складатимуть кібер-простір глобального села» [6; 76].

Проте простір віртуальної реальності не лише спонукає до творення онлайн-ринку, на якому більшість 3 нас є покупцями, продавцями товарів і послуг; але від матеріальних речей спонукає міркувати про ринок, який спонукає до самопрезентації і самобрендингу в Мережі. Саме тому в Інтернеті не лише можна говорити про бренди певних товарів, марок, але й про бренди особистостей, серед яких популярні громадянські веб-журналісти, яким довіряє громадськість [6; 348]. Важливо зазначити, що віртуальна реальність також у цій глобальній панорамі творить лідерів думок, тих, кого найбільше читають у соціальних мережах чи на порталах суспільно-політичних веб-ресурсів. Це особистості, які необов'язково є журналістами, зазвичай просто активними громадянами, які прагнуть виокремити лінію конструктивних дискусій і таким чином творити навколо себе спільноти у глобальному вимірі світового базару.

Отож, як ми з'ясували вище, зважаючи на простір віртуальної реальності, їі специфіку та можливості, виникає ціла плеяда нових медій, які мають на меті поєднувати кордони, змінювати настрої, думки, зрештою, відкривати нові цифрові та інформаційні перспективи, удосконалювати журналістику і медіасвіт. Проте цього знову-таки недостатньо, зважаючи на попит швидкого науково-технічного виміру. Адже онлайн-особистість - це не реальна особа. Нікнейми та несправжні аватарки є якраз влучними ідентифікаторами невпинного розвитку світу віртуальної реальності, а отже потреби переформатування теперішнього новомедійного виміру для більш комфортного спілкування і задоволення своїх інформаційних потреб.

Примітно, що через міжперсональну комунікацію, потреби у вимірі віртуальної реальності, змінюється панорамність новомедійного простору, з’являються нові нові 
медіа. Саме цей термін впровадив американський дослідник Пол Левінсон у своїй праці «New New Media» [6; c.10]. Саме новими новими медіа він називає платформи формату Web 2.0 - Facebook, Twitter та інші, які є більш модерними, ніж застарілі версії веб-сайтів або опція е-мейлів, а отже сервіси, які можливо віднести до епохи Web 1.0.

На думку Пола Левінсона, нові нові медіа мають такі характерні особливості:

1. Кожен споживач - інформаційний продуцент;

2. Ти отримуєш те, за що ти не платиш (на відміну від нових медій - Amazon, iTunes, що пропонують платні послуги). Левінсон називає платформи Blogspot i Wordpress, які абсолютно безкоштовні.

3. Конкуренція і взаємна каталітичність. Дослідник пояснює, що деякі нові медіа виникають, не знаходять свого користувача і гинуть, натомість з'являються нові нові медіа, що відповідають всім інформаційним запитам.

4. Нові нові медіа в підсумку над користувацьким контролем [6;3].

Тому, підсумовуючи проаналізоване, можемо зазначити, що віртуальна реальність створює для нас паралельний простір комунікації, який нібито має власні правила гри, але надто подібний до нашого матеріального світовиміру. Цифрові можливості та феномен віртуальної реальності дозволяють розширювати межі комунікації, а тому творити простір нових та нових нових медіа, що мають на меті не лише слугувати платформами для комунікації, але й обміну, продажу, взаємодоповнення. Не виключено, що подібно до формування простору Web 3.0, про яку вже зазначають чимало дослідників, зміниться і підхід до новомедійної термінології, не виключено, що відбудеться з'ява ще одного терміна - нові нові нові медіа або нові медіа 3.0, подібно до визначення цифрової епохи. Творення віртуальної реальності дозволяє зафіксувати певне комунікаційне безсмертя, про що ми згадували вище, зокрема покликаючись на феномен віртуальних кладовищ, адже втрата комуніката у реальному світі не означає його ліквідацію у віртуальності.

\section{REFERENCES}

1. Culture of the Internet // Sara Kiesler. Mahwah, NJ : Erlbaum. 1997. 463 p.

2. Digital Divide // Eva Johanna Schweitzer. Encyclopædia Britannica, Inc., 2008.

3. Digital McLuchan // Paul Levinson. Routlage, London. 1999.

4. Discourse 2.0: Language and New Media // Deborah Tannen and Anna Marie Trester. Georgetown University Press, 2013. 258 p.

5. New Media a critical introduction // Martin Lister, Jon Dovey, Seth Giddings, Iain Grant and Kieran Kelly. 2nd ed. 446 p.

6. New new media / Paul Levinson. Previous ed.: Boston, Mass.: Pearson, 2009.

7. The New Media Reader / Edited by Noah Wardrip - Fruin and Nick Montfort / The Mit Press. Cambridge, Massachusetts. 2003. 823 p.

8. The soft edge : a natural history and future of the information revolution // Paul Levinson. London, 1997. $257 \mathrm{p}$.

9. The Internet imaginaire / Patrice Flichy; translated by Liz Carey. Libbrecht. 2007. Massachusetts Institute of Technology

10. Understanding the web : social, political, and economic dimensions of the internet // Alan B. Albarran. Ames, Iowa : Iowa State Univ. Press, 2000. 


\title{
VIRTUAL REALITY IN THE NEW MEDIA SYSTEM
}

\author{
Yuliana Lavrysh \\ Ivan Franko National University of Lviv, \\ Generala Chuprynky Str., 49, 79044, Lviv, Ukraine \\ e-mail: newmedialnu085@gmail.com \\ https://orcid.org/0000-0002-5205-9309
}

The publication presents the space of virtual reality, its specificity and importance for the formation and development of new media. Virtual reality is not an illusion, but a parallel reality created with the help of digital technologies. Virtual reality and real reality are two dimensions that coexist in a technological society. It is the virtual reality space that allows you to discover new media opportunities, which allows you to reach not only another level of information but also broadens the horizons for the media market.

Challenges of the digital era, the Web 2.0 format, give us the opportunity to plunge into the Web space more and more, looking for answers to these or other questions. In the end, the concepts that we have researched and used before, give reason to think about new challenges. For example, the term «social network», begun in 1954 by James Barnes, meant the concept was completely different. Social network meaning a certain group of people, based on the experiment of Barnes - are parishioners of one of the parishes in Norway, who outside the church were not actively communicating. The researcher tried to understand how this social group functions through meetings in the temple, its communication capabilities. Today, the «social network» is a multi-format phenomenon, considering the measurement of Web 2.0. This is not only a satisfaction of communication needs, but also the use of all the main characteristics of the network space: multimedia, interactivity, the creation of a virtual personality, the ability to feedback, image creation.

Therefore, the space of virtual reality, unlike reality, is not limited to territorial, national, linguistic boundaries. Members of this online community are residents of the world. And this, in turn, allows virtual reality to create a global market for ideas and new concepts.

Virtual reality creates for us a parallel space of communication, which supposedly has its own rules of the game, but is very similar to our material worldview. Digital capabilities and the phenomenon of virtual reality allow you to expand the boundaries of communication, and therefore create space for new and new new media, aimed not only to serve as platforms for communication, but also for the exchange, sale, complementarity. The creation of virtual reality allows us to fix a certain communicative immortality, as we mentioned above, in particular by referring to the phenomenon of virtual cemeteries, since the loss of a communicator in the real world does not mean its elimination in virtue.

Key words: virtual reality, new media, new new media, Web 2.0. 